\title{
Pengukuran Usability pada Website Kampus Akademi Komunitas Negeri Pacitan Menggunakan System Usability Scale (SUS)
}

\author{
Gramandha Wega Intyanto1), Narandha Arya Ranggianto2), Vika Octaviani3) \\ 1)Tatalaksana Studio Produksi, Akademi Komunitas Negeri Pacitan \\ 2)Teknik Informatika, Institut Teknologi Sepuluh Nopember \\ 3)Rekayasa Perangkat Lunak, SMK Negeri 1 Gending, Probolinggo \\ 1)gramandha@aknpacitan.ac.id, 2)6025211010@mhs.its.ac.id,3)vika071090@gmail.com
}

\begin{abstract}
In the education world, the website is useful in providing related to the website owner's agency and also promotional media, such as on the Akademi Komunitas Negeri Pacitan website campus. Visitors or users also have a big influence on the website. These are some of the things that prompted us to analyze the usability of Akademi Komunitas Negeri Pacitan website campus, where measurement and analysis using the System Usability Scale (SUS) was carried out with a valid test which stated that it was valid with the results of Rcount > Rtable on the questionnaire item and the reliability test results of 0.637 which stated reliable. The result of the score on the Akademi Komunitas Negeri Pacitan website campus is 60.75, where it gets a D predicate, OK category, the level of acceptance (feel) of visitors is low margin and the Net Promoter Score (NPS) point of view based on SUS score is stated the detractor. These results describe that it is considered not yet effective, efficient, satisfactory for users/visitors, and not usable yet.
\end{abstract}

Keywords: Pengukuran, Usability, System Usability Scale (SUS), Website

\begin{abstract}
Abstrak
Pada dunia pendidikan website memiliki peran penting dalam memberikan informasi terkait dengan instansi pemilik website dan juga media promosi. Salah satu website pada lingkungan pendidikan yaitu website kampus Akademi Komunitas Negeri Pacitan. Pengunjung atau pengguna juga memiliki pengaruh besar terhadap website. Beberapa tinjauan tersebut yang mendorong kami dalam penganalisaan usability website kampus Akademi Komunitas Negeri Pacitan, yang mana pengukuran dan analisa menggunakan System Usability Scale (SUS) yang dilakukan uji validitas yang menyatakan valid dengan hasil Rhitung > Rtabel pada item kuesioner dan uji Reliabilitas dengan hasil 0.637 yang menyatakan reliabel. Hasil Skor pada website kampus Akademi Komunitas Negeri Pacitan yaitu 60,75, dimana mendapat predikat D, kategori OK, tingkat penerimaan ( $\mathrm{feel}$ ) pengunjung yaitu margin low dan sudut pandang Net Promoter Score (NPS) berdasarkan skor SUS dinyatakan bahwa berpotensi detractor. Hasil ini menjabarkan bahwa dianggap belum efektif, efisien dan memuaskan bagi pengguna/pengunjung serta belum usable.
\end{abstract}

Kata Kunci: Pengukuran, Usability, System Usability Scale (SUS), Website 


\section{PENDAHULUAN}

Pada era industri 4.0, dunia pendidikan memiliki perubahan pola perilaku dalam penggunaan teknologi di lingkungan dalam maupun di luar kampus, khususnya dalam pemanfaatan teknologi internet. Internet bahkan digunakan sebagai media bertukar informasi dan komunikasi dalam proses akademisi atau pendidikan. Proses akademi isi biasanya dilakukan paling sering melalui website pembelajaran elearning kampus, (Nugroho et al., 2020) bukan hanya itu salah satu contohnya yaitu website utama kampus Akademi Komunitas Negeri juga digunakan sebagai media akses informasi untuk mengetahui kalender akademi, update informasi perkuliahan, berbagai kegiatan yang dilakukan di lingkungan kampus. Penggunaan dari website kampus Akademi Komunitas Negeri Pacitan juga memiliki banyak manfaat dalam pertukaran informasi, bahkan juga dapat digunakan sebagai media promosi di lingkungan luar kampus.

Dari penjabaran pemanfaatan website kampus Akademi Komunitas Negeri Pacitan, kami meninjau hal yang mendasar untuk mengetahui sejauh mana website ini dapat digunakan pengguna secara efektif, efisiensi, dan puas dalam konteks penggunaan atau pengunjung website untuk mencapai tujuan tertentu. Pengukuran yang mencakup beberapa hal tersebut yaitu mengarah pada pengukuran usability (Salamah, 2019),(Beny et al., 2019) dimana Internasional Standar Organization (ISO) bahwa usability (Standard, 1998), (Erawati et al., 2018), sebagai berikut:

1. Efektivitas, ketika pengguna menjalankan aktivitas pada produk/website, pengguna akan merasa tercapai apa yang diinginkan (mencapai tingkat akurasi dan kesempurnaan).

2. Efisiensi, yang mana menunjukkan sumber daya yang digunakan dalam produk/website, seperti halnya mudah dimengerti, tidak rumit, hemat waktu, dsb.

3. Kepuasan, yang mana pengguna memberikan respon perilaku positif terhadap produk/website dan merasa bebas dari ketidaknyamanan.

Definisi dari usability juga dijabarkan oleh Nielsen pada tahun 2012 dimana usability merupakan penilaian terhadap antarmuka dalam seberapa mudah digunakan. Perancangan sistem yang terstruktur dan baik akan menghasilkan antarmuka yang mudah dalam interaksi oleh penggunanya. (Stone et al., 2005), (Handayani \& Adelin, 2019) Perancangan antarmuka dengan baik juga dapat membuat pengunjung website akan kembali berkunjung (Salamah, 2019), (H.N et al., 2015) dan meningkatkan kepuasan dari pengunjung. (Suyanto \& Ependi, 2019) Pada kondisi kebalikannya, dimana bila antarmuka tidak dirancang dengan baik maka akan menimbulkan rasa frustrasi, ketidakpuasan, serta mengurangi $40 \%$ pengujung akan berkunjung kembali. (Stone et al., 2005), (Marcus, 2002)

Setelah menarik beberapa kesimpulan dari penjabaran mengenai usability, kami memiliki tujuan dari penelitian ini yaitu dapat menganalisa hasil pengujian website kampus Akademi Komunitas Negeri Pacitan dengan menggunakan metode SUS, dimana pengukuran SUS ini juga disebut uji usability yang "quick and dirty". (Ependi et al., 2019), (W Wahiddin, A R Syulistyo*, 2021) Pada proses analisa kami menarik hasil dari sudut padang 
acceptability, grade scale, adjective rating dan juga mengukur korelasi antara SUS (Muqoddas et al., 2020) dan Net Promoter Score (NPS) yang mana membagi menjadi tiga bagian kelas detractor, passive, dan promoter. (Pradini et al., 2019)

\section{METODE}

Subjek pada yang diteliti yaitu website kampus Akademi Komunitas Negeri Pacitan yang memiliki alamat domain www.aknpacitan.ac.id, tertera pada Gambar 1. Pada penelitian ini menggunakan metode uji yaitu SUS, atau kepanjangan dari System Usability Scale. (Brooke, 1996), (Brooke, 2013) kemudian dilakukan uji validitas untuk menyatakan apakah kuesioner yang digunakan valid serta uji reliabilitas untuk mengetahui hasil pengukuran apakah reliable atau konsisten.

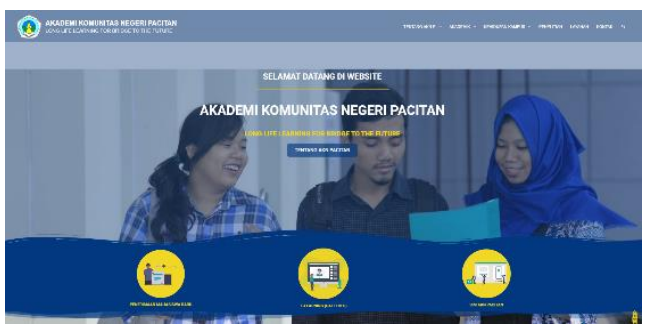

Gambar 1. Website Akademi Komunitas Negeri Pacitan (http://aknpacitan.ac.id/)

\subsection{Metode SUS}

Pengukuran usability pada sistem komputer (website atau aplikasi) yang menggunakan metode SUS berdasarkan pandangan subyektif pengguna yaitu memiliki beberapa keunggulan sebagai berikut:

a. Hasil Pengujian SUS berupa skala yaitu skor 0-100 sehingga dapat digunakan dengan mudah. (Brooke, 1996), (Bangor et al., 2009)

b. SUS proses kalkulasi atau perhitungan mudah dimengerti atau tidak rumit. (Ependi et al., 2019) c. SUS dapat digunakan tanpa biaya tambahan atau tersedia gratis. (Gardner, 2011)

d. SUS biasanya digunakan dengan ukuran sample kecil tetapi terbukti valid dan konsisten atau reliabel. (Brooke, 2013)

Tabel 1. Instrumen pada SUS

\begin{tabular}{|c|c|}
\hline Kode & Pernyataan pada Kuesioner \\
\hline R1 & $\begin{array}{lr}\text { Saya akan } & \text { sering menggunakan } \\
\text { atau mengunjungi website kampus } \\
\text { Akademi } & \text { Komunitas Negeri } \\
\text { Pacitan } & \end{array}$ \\
\hline R2 & $\begin{array}{lrr}\text { Saya menilai website } & \text { kampus } \\
\text { Akademi Komunitas } & \text { Negeri } \\
\text { Pacitan mudah dijelajahi } & \\
\end{array}$ \\
\hline R3 & $\begin{array}{l}\text { Saya menilai website } \\
\text { Akademi Komunitas }\end{array}$ \\
\hline R4 & $\begin{array}{l}\text { Saya harus dibantu teknis pada } \\
\text { saat mengunjungi website kampus } \\
\text { Akademi Komunitas Negeri } \\
\text { Pacitan }\end{array}$ \\
\hline R5 & $\begin{array}{l}\text { Saya menilai fitur atau fungsi yang } \\
\text { tersedia pada website kampus AK } \\
\text { Pacitan dibangun dan dirancang } \\
\text { secara baik }\end{array}$ \\
\hline R6 & 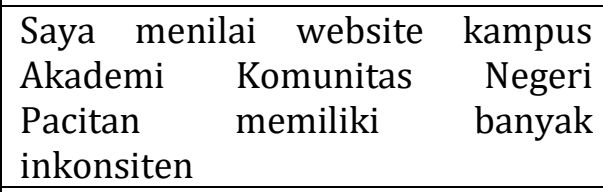 \\
\hline R7 & $\begin{array}{l}\text { Saya berpendapat orang yang } \\
\text { menjelajah } \quad \text { website } \\
\text { Akademi Komunitas } \\
\text { Pacitan dengan cepat }\end{array}$ \\
\hline R8 & $\begin{array}{lr}\text { Saya menilai website } & \text { kampus } \\
\text { Akademi Komunitas } & \text { Negeri } \\
\begin{array}{l}\text { Pacitan sangat rumit } \\
\text { dikunjungi }\end{array} & \\
\end{array}$ \\
\hline R9 & $\begin{array}{lcr}\text { Saya percaya diri } & \text { ketika } \\
\text { menjelajah } & \text { website } & \text { kampus } \\
\text { Akademi } & \text { Komunitas } & \text { Negeri } \\
\text { Pacitan } & & \\
\end{array}$ \\
\hline R10 & $\begin{array}{l}\text { Saya butuh belajar beberapa hal } \\
\text { sebelum mengunjungi } \text { website } \\
\text { Akademi Komunitas Negeri } \\
\text { Pacitan dengan baik }\end{array}$ \\
\hline
\end{tabular}


Pada Tabel 1. Menunjukkan 10 item pernyataan dari kuesioner SUS yang merujuk dari referensi John Brooke. Pada SUS tiap pernyataan kuesioner menggunakan 5 point skala Likert dimana responden diharuskan mengisi 10 item pertanyaan SUS untuk memberikan penilaian yang bersifat subyektif dari beberapa pilihan berikut:

- Sangat tidak setuju = 1

- Tidak setuju = 2

- Netral = 3

- Setuju = 4

- Sangat setuju = 5

Skala titik tengah atau disebut netral digunakan untuk penilaian yang tidak menemukan penilaian yang tepat. (Brooke, 1996), (Prabowo \& Suprapto, 2021) Persamaan 1 merupakan pperhitungan matematis yang digunakan untuk metode SUS.

Skor SUS $=(((P t 1-1)+$

$(5-P t 2)+(P t 3-1)+(5-P t 4)+$

$(P t 5-1)+(5-P t 6)+(P t 7-1)+$

$(5-P t 8)+(P t 9-1)+$

$(5-P t 10)) * 2.5)$

Pada tiap pernyataan kuesioner memiliki skor kontribusi yang berskala kisaran 0 hingga 4. Dimana, pada item pertanyaan digolongkan menjadi 2 yaitu item pertanyaan yang bernilai positif dan negatif. [10] Item pertanyaan ganjil $(1,3,4,5,6$, dan 9) memiliki skor atau nilai kontribusi yaitu nilai skala item dikurangi nilai 1 . Pada item pertanyaan genap $(2,4,6,8$ dan 10), skor atau nilai kontribusi diukur nilai 5 yang dikurangi dari nilai skala item. Dari seluruh penjumlahan skor dikalikan dengan 2.5. Hasil Akhir berkisar 0 hingga 100. Sedangkan nilai keseluruhan didapat dari nilai rata-rata skor dari kalkulasi skor SUS keseluruhan nilai individu pada Persamaan 2.

$$
S U S_{\text {Total }}=\sum_{0}^{n} \text { Skor } S U S_{n}
$$

Kuesioner disebarkan kepada pengguna untuk diambil data dengan menggunakan google form. Proses pengambilan data melalui sosial media, seperti WhatsApp personal atau group. Penyebaran kuesioner dilakukan pada tangga 4 hingga 15 Januari 2021. Kuesioner yang disebar telah diisi oleh sebanyak 34 responden yang sudah pernah mengunjungi website kampus Akademi Komunitas Negeri Pacitan sesuai referensi Roscoe menyebutkan bahwa jumlah total sampel layak pada penelitian antara 30 sampai dengan 500 responden. (Sugiyono, 2014) Responden pada penelitian ini yaitu terdiri dari 19 mahasiswa, 5 pegawai/staff, 6 dosen Akademi Komunitas Negeri Pacitan, dan 4 umum (luar lingkungan Akademi Komunitas Negeri Pacitan). Keseluruhan responden memiliki range usia mulai dari 18-45 tahun.

Proses dalam pengolahan data untuk mendapatkan skor SUS yaitu sebagai berikut:

a. Pada hasil pilihan atau jawaban dari responden dikonversikan pilihannya menjadi angka skala linkert 1 s.d. 5.

b. Tahapan selanjutnya yaitu menghitung nilai Skor SUS menggunakan Persamaan 2. Pada Tabel 2 menjelaskan detail dari hasil perhitungan nilai skor SUS dan hasilnya nilai rata-rata dari total skor SUS yaitu sebesar 60,75 yang nantinya akan digunakan sebagai acuan analisa nilai Skor SUS pada website kampus Akademi Komunitas Negeri Pacitan. 
Tabel 2. Hasil Data SUS

\begin{tabular}{|c|r|r|r|r|r|r|r|r|r|r|r|}
\hline RESPODEN & Pt1 & Pt2 & Pt3 & Pt4 & Pt5 & Pt6 & Pt7 & Pt8 & Pt9 & Pt10 & SKOR SUS \\
\hline $\mathbf{1}$ & 4 & 2 & 4 & 2 & 4 & 2 & 4 & 2 & 5 & 2 & 77.5 \\
\hline $\mathbf{2}$ & 4 & 2 & 3 & 2 & 4 & 2 & 4 & 2 & 4 & 2 & 72.5 \\
\hline $\mathbf{3}$ & 4 & 3 & 3 & 4 & 4 & 3 & 4 & 3 & 4 & 3 & 57.5 \\
\hline $\mathbf{4}$ & 3 & 3 & 3 & 2 & 4 & 2 & 4 & 2 & 4 & 2 & 67.5 \\
\hline $\mathbf{5}$ & 4 & 3 & 4 & 3 & 4 & 3 & 5 & 2 & 4 & 2 & 70 \\
\hline $\mathbf{6}$ & 4 & 3 & 3 & 3 & 4 & 2 & 4 & 2 & 4 & 2 & 67.5 \\
\hline $\mathbf{7}$ & 3 & 3 & 2 & 3 & 3 & 3 & 3 & 4 & 3 & 3 & 45 \\
\hline $\mathbf{8}$ & 3 & 2 & 3 & 2 & 4 & 2 & 4 & 2 & 4 & 2 & 70 \\
\hline $\mathbf{9}$ & 4 & 3 & 3 & 3 & 4 & 3 & 4 & 3 & 4 & 3 & 60 \\
\hline $\mathbf{1 0}$ & 4 & 3 & 4 & 3 & 4 & 2 & 3 & 2 & 3 & 2 & 65 \\
\hline $\mathbf{1 1}$ & 4 & 3 & 3 & 4 & 4 & 3 & 4 & 3 & 4 & 3 & 57.5 \\
\hline $\mathbf{1 2}$ & 4 & 2 & 3 & 3 & 3 & 3 & 3 & 2 & 4 & 3 & 60 \\
\hline $\mathbf{1 3}$ & 5 & 3 & 4 & 3 & 4 & 3 & 4 & 3 & 3 & 3 & 62.5 \\
\hline $\mathbf{1 4}$ & 3 & 3 & 3 & 3 & 4 & 3 & 4 & 3 & 4 & 3 & 57.5 \\
\hline $\mathbf{1 5}$ & 3 & 3 & 3 & 3 & 4 & 3 & 4 & 3 & 3 & 3 & 55 \\
\hline $\mathbf{1 6}$ & 4 & 3 & 3 & 3 & 4 & 3 & 4 & 2 & 5 & 3 & 65 \\
\hline $\mathbf{1 7}$ & 4 & 3 & 3 & 4 & 4 & 2 & 4 & 2 & 4 & 3 & 62.5 \\
\hline $\mathbf{1 8}$ & 4 & 3 & 3 & 4 & 4 & 3 & 4 & 3 & 4 & 3 & 57.5 \\
\hline $\mathbf{1 9}$ & 3 & 3 & 3 & 4 & 3 & 3 & 3 & 2 & 3 & 3 & 50 \\
\hline $\mathbf{2 0}$ & 2 & 3 & 3 & 4 & 3 & 2 & 3 & 3 & 4 & 2 & 52.5 \\
\hline $\mathbf{2 1}$ & 3 & 3 & 3 & 3 & 4 & 3 & 4 & 3 & 4 & 3 & 57.5 \\
\hline $\mathbf{2 2}$ & 4 & 3 & 2 & 2 & 3 & 2 & 4 & 2 & 3 & 2 & 62.5 \\
\hline $\mathbf{2 3}$ & 4 & 4 & 4 & 3 & 4 & 3 & 4 & 2 & 4 & 3 & 62.5 \\
\hline $\mathbf{2 4}$ & 3 & 2 & 3 & 3 & 4 & 2 & 4 & 2 & 4 & 2 & 67.5 \\
\hline $\mathbf{2 5}$ & 3 & 3 & 3 & 3 & 4 & 3 & 4 & 3 & 4 & 3 & 57.5 \\
\hline $\mathbf{2 6}$ & 4 & 3 & 3 & 3 & 3 & 2 & 4 & 2 & 3 & 3 & 60 \\
\hline $\mathbf{2 7}$ & 3 & 3 & 2 & 2 & 2 & 2 & 3 & 2 & 3 & 3 & 52.5 \\
\hline $\mathbf{2 8}$ & 4 & 2 & 2 & 3 & 3 & 3 & 4 & 2 & 4 & 3 & 60 \\
\hline $\mathbf{2 9}$ & 4 & 3 & 3 & 3 & 3 & 3 & 3 & 2 & 3 & 3 & 55 \\
\hline $\mathbf{3 0}$ & 3 & 2 & 3 & 3 & 4 & 2 & 4 & 2 & 4 & 2 & 67.5 \\
\hline $\mathbf{3 1}$ & 3 & 2 & 3 & 3 & 4 & 2 & 4 & 2 & 4 & 2 & 67.5 \\
\hline $\mathbf{3 2}$ & 3 & 2 & 3 & 2 & 4 & 3 & 4 & 2 & 3 & 3 & 62.5 \\
\hline $\mathbf{3 3}$ & 4 & 3 & 3 & 3 & 4 & 3 & 4 & 2 & 4 & 3 & 62.5 \\
\hline $\mathbf{3 4}$ & 4 & 3 & 3 & 3 & 3 & 3 & 3 & 2 & 3 & 3 & 55 \\
\hline & & & Rata-rata Nilai SUS & & & & & $\mathbf{6 0 . 7 5}$ \\
\hline
\end{tabular}

\subsection{Uji Validitas}

Tahapan yang ketiga yaitu uji validitas yang hasilnya ditampilkan pada Tabel 3. Uji validitas memiliki tujuan dalam mengetahui ketepatan dan kecermatan dalam melakukan pengukuran pada alat ukur yang digunakan. (Azwar, 2016) Selain itu validitas digunakan untuk menunjukkan variable yang diukur memang sesuai dengan variabel yang akan diteliti, dikatakan valid ketika item pertanyaan mengungkap hal yang diukur. Hasil pengukuran uji validasi yang valid berupa koefisien korelasi pada taraf signifikan $(0,05)$ terhadap skor total dan uji validitas pada penelitian ini menggunakan Pearson (2 tail). Kondisi Rhitung > Rtabel maka hasil uji validitas dianggap valid, dimana Rtabel memiliki nilai sebesar 0,339. Hasil Data 10 item pernyataan pada kuesioner memiliki nilai Rtabel memiliki lebih kecil pada nilai Rhitung, sehingga hasil ini menyatakan 
bahwa pernyataan kuesioner dianggap valid $(\mathrm{Vd})$.

Tabel 3. Hasil Uji Validitas Data

Kuesioner

\begin{tabular}{|c|c|c|c|}
\hline & Rhitung & Rtabel & Keterangan \\
\hline Pt1 & 0.459 & 0.339 & Vd \\
\hline Pt2 & 0.473 & 0.339 & Vd \\
\hline Pt3 & 0.487 & 0.339 & Vd \\
\hline Pt4 & 0.558 & 0.339 & Vd \\
\hline Pt5 & 0.578 & 0.339 & Vd \\
\hline Pt6 & 0.630 & 0.339 & Vd \\
\hline Pt7 & 0.438 & 0.339 & Vd \\
\hline Pt8 & 0.432 & 0.339 & Vd \\
\hline Pt9 & 0.355 & 0.339 & Vd \\
\hline Pt10 & 0.450 & 0.339 & Vd \\
\hline
\end{tabular}

\subsection{Uji Reliabilitas}

Pada penelitian ini, proses uji reliabilitas dilakukan secara bersama pada tiap pertanyaan dan yang digunakan metode Cronbach's Alpha (a). Hasil pengukuran mendapat nilai konsisten pada saat dilakukan dua kali atau lebih. (Suryabrata, 1998)
Tabel 4. Hasil Uji Reliabilitas Data Kuesioner (Reliability Statistics)

\begin{tabular}{|c|c|c|}
\hline Metode (a) & Jumlah Item & Keterangan \\
\hline 0.637 & 10 & Reliabel \\
\hline
\end{tabular}

Hasil uji reliabilitas yaitu 0,637 untuk 10 pernyataan kuesioner sehingga pada hasil uji reliabilitas dianggap reliabel sesuai dengan rujukan menurut Sujarweni Wiratna, dimana ketika nilai alpha lebih dari (>) 0,60 maka butir pertanyaan pada kuesioner reliabel. (Sujarweni, 2015)

\section{HASIL DAN PEMBAHASAN}

Skor SUS 60,75yang sudah dinyatakan valid dan reliabel dari proses penyebaran kuesioner kepada responden. Hasil ini dijelaskan detail pada Tabel I, dimana hasil ini dilakukan analisa skor SUS dari sudut pandang acceptability, grade scale, adjective rating dan juga mengkorelasikan dengan Net Promater Score (NPS) yang nantinya akan dianalisa pada pengukuran Gambar 2.

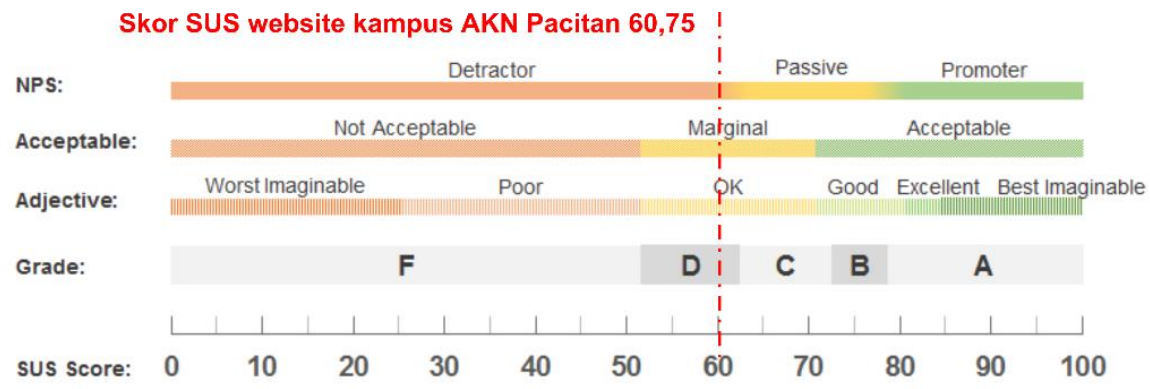

Gambar 2. Pengukuran SUS dari 4 Sudut Pandang (Grade, Adjective, Acceptable, NPS) (Muqoddas et al., 2020)

Skor SUS dilihat dari kecenderungan Net Promoter Score (NPS) yaitu pengguna berpotensi menjadi Promoter jika nilai sebesar 82 atau lebih (pengguna yang berpotensi memberikan respon positif atau meningkatkan promosi dari website) nilai skor SUS kurang dari 67 menunjukkan pengguna berpotensi menjadi Detractor (pengguna yang berpotensi memberikan respon negatif dan dianggap dapat menurunkan jumlah pengguna) dan kondisi skor diantara lebih dari 67 dan kurang dari 82 pengguna berpotensi Passive (pengguna yang berpotensi 
memberikan respon netral atau tidak memberikan respon positif maupun negatif). (Bain \& Company, Inc., Satmetrix Systems, Inc., 2020) Pada website kampus Akademi Komunitas Negeri Pacitan yang memiliki nilai skor 60,75dijabarkan pada Gambar 3 menunjukkan pengguna yang berpotensi menjadi detractor. Hal ini masih dianggap aman atau netral dikarenakan masih dianggap tidak memberikan penurunan jumlah pengguna.Pada Gambar 4 menunjukkan bahwa Skor SUS website kampus Akademi Komunitas Negeri Pacitan sebesar 60,75 yang masuk dalam kategori Margin Low atau website ini dianggap dapat diterima oleh pengguna. Dari Skor SUS dianggap OK pada sudut pandang Adjective jika memiliki nilai lebih dari 60,75. (Bangor et al., 2009) Skor SUS pada website kampus Akademi Komunitas Negeri Pacitan yang memiliki nilai 60,75 masuk dalam kategori OK.

Pada penelitian Sauro pada tahun 2011 menjelaksan bahwa kategori sus berdasarkan grade atau predikat, dimana ada 5 predikat yaitu predikat $A$, predikat $B$ yaitu bernilai lebih dari sama dengan ( $\geq$ ) 74 dan kurang dari sama dengan ( $\leq$ ) 80,3, predikat $C$ yaitu skor memiliki kisaran lebih dari (>) 68 dan kurang dari $(<) 74$, dan predikat D yaitu skor memiliki kisaran lebih dari sama dengan ( $\geq$ ) 51 dan kurang dari (<) 68 . (Sauro, 2011) Hasil skor SUS website kampus Akademi Komunitas Negeri Pacitan sebesar 60,75 yaitu mendapatkan predikat D yang ditunjukkan pada Gambar 6.

Dari proses penganalisaan skor SUS dari 4 sudut pandang yaitu adjective rating, acceptability, grade scale, dan Net Promater Score (NPS) hasil subyektif menyatakan bahwa website kampus Akademi Komunitas Negeri Pacitan masih dianggap kurang efektif, efisien dan memuaskan bagi pengguna sehingga website perlu adanya evaluasi dan pengembangan lebih lanjut, selain itu perlu melakukan penelitian lanjutan untuk mengidentifikasi masalah dari hasil skor SUS yang didapat. Hal ini dikarenakan hasil dari SUS memiliki sifat tidak atau bukan diagnosik sehingga untuk mengidentifikasi masalah perlu menggunakan metode evaluasi yang lain.

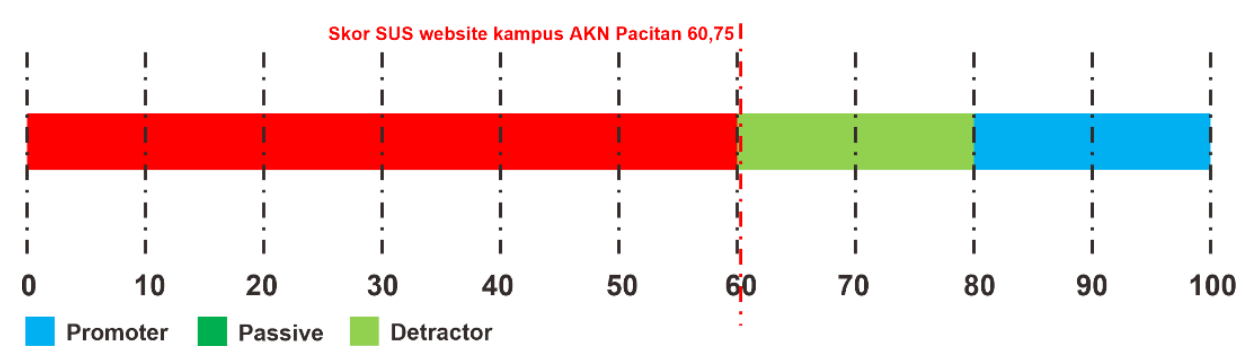

Gambar 3. Nilai NPS berdasarkan skor SUS website kampus Akademi Komunitas Negeri Pacitan 


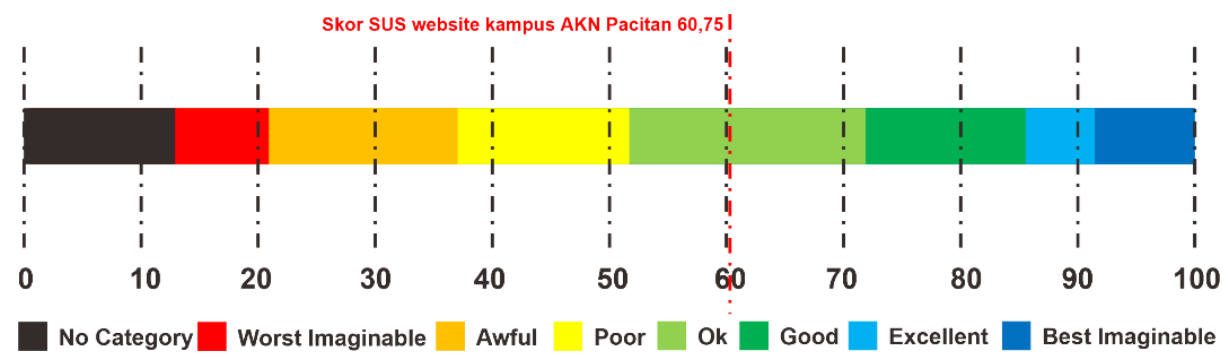

Gambar 4. Nilai adjective berdasarkan skor SUS website Kampus Akademi Komunitas Negeri Pacitan

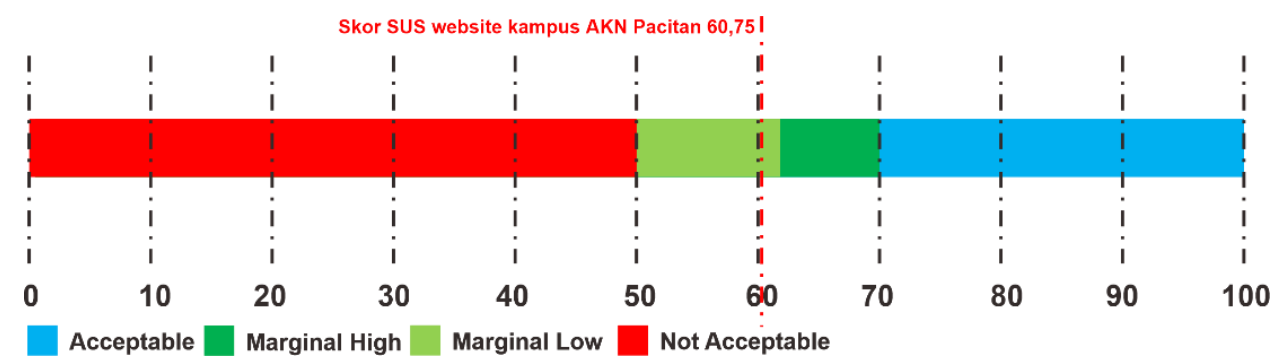

Gambar 5. Nilai acceptable atau tingkat penerimaan pengunjung berdasarkan Skor SUS website kampus Akademi Komunitas Negeri Pacitan

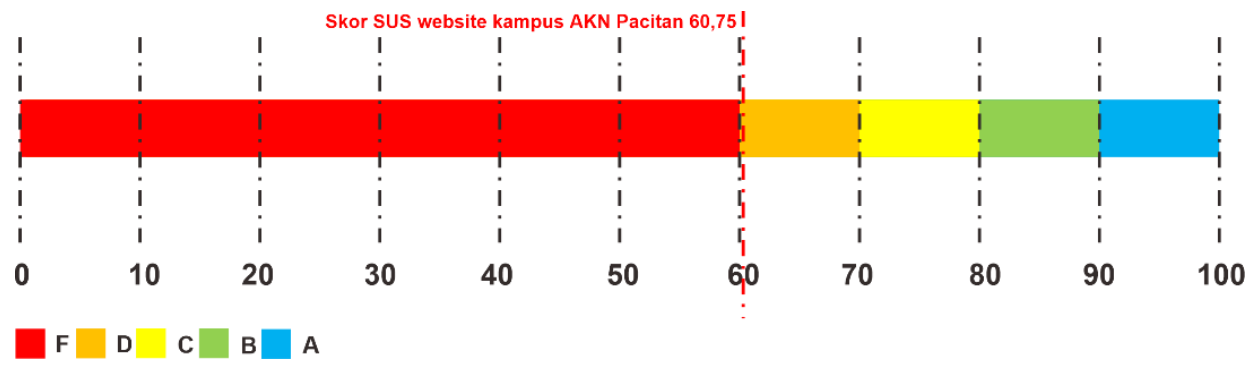

Gambar 6. Nilai grade atau predikat berdasarkan Skor SUS website kampus Akademi Komunitas Negeri Pacitan

\section{KESIMPULAN}

Penarikan kesimpulan dengan pengukuran usability dengan SUS, dimana hasil pengujian yang dilakukan terhadap website Akademi Komunitas Negeri Pacitan yaitu skor SUS-nya bernilai 60,75. Hasil SUS website Akademi Komunitas Negeri Pacitan dianalisa dari sudut pandang NPS dinyatakan bahwa berpotensi detractor, dari segi kepuasan pengunjung dinyatakan margin low, untuk (grade) predikat $\mathrm{D}$ dengan adjective range $\mathrm{OK}$, data ini menyimpulkan bahwa website kampus Akademi Komunitas Negeri Pacitan masih memiliki indikasi tidak memuaskan bagi pengguna, kurang efektif, dan efisien. Hasil ini juga menyatakan bahwa website kampus Akademi Komunitas Negeri Pacitan sebagai sarana media informasi online masih belum usable, yang memiliki potensi penurunan minat pengguna. 


\section{REFERENCE}

Azwar, S. (2016). Reliabilitas Dan Validitas Aitem. In Buletin Psikologi (Vol. 3, Issue 1). Yogyakarta: Pustaka Pelajar. https://doi.org/10.22146/bpsi.13381

Bain \& Company, Inc., Satmetrix Systems, Inc., F. R. (2020). Net Promoter System. Bain \& Company, Inc., Satmetrix Systems, Inc., Fred Reichheld. https://www.netpromotersystem.com/about/measuring-your-net-promoterscore/

Bangor, A., Staff, T., Kortum, P., Miller, J., \& Staff, T. (2009). Determining what individual SUS scores mean: adding an adjective rating scale. Journal of Usability Studies (JUS), 4(3), 114-123.

Beny, B., Yani, H., \& Ningrum, G. M. (2019). Evaluasi Usability Situs Web Kemenkumham Kantor Wilayah Jambi dengan Metode Usability Test dan System Usability Scale. RESEARCH : Computer, Information System \& Technology Management, 2(1), 30. https://doi.org/10.25273/research.v2i1.4282

Brooke, J. (1996). SUS-A quick and dirty usability scale. Usability Evaluation in Industry, 4-7.

Brooke, J. (2013). SUS: A Retrospective. Journal of Usability Studies (JUS), 8(2), 29-40.

Ependi, U., Kurniawan, T. B., \& Panjaitan, F. (2019). System Usability Scale Vs Heuristic Evaluation: a Review. Simetris: Jurnal Teknik Mesin, Elektro Dan Ilmu Komputer, 10(1), 65-74. https://doi.org/10.24176/simet.v10i1.2725

Erawati, N. wayan E., Arthana, I. K. R., \& Pradnyana, I. M. A. (2018). Usability Testing Dengan Iso/Iec 9126-4 Sistem Informasi Akademik Universitas Pendidikan Ganesha Ditinjau Dari Pengguna Dosen. Jurnal Pendidikan Teknologi Dan Kejuruan, 15(2), 287-297. https://doi.org/10.23887/jptk-undiksha.v15i2.14502

Gardner, J. S. (2011). Aesthetics of spatial composition: Facing, position, and context, and the theory of representational fit. In A. R. R. J. S. G. Copyright (C) 2011 (Ed.), A dissertation submitted for the degree of Doctor of Philosophy in University of California, Berkeley (Spring 201, p. 91).

H.N, I. A., Nugroho, P. I., \& Ferdiana, R. (2015). Pengujian Usability Website Menggunakan System Usability Scale. JURNAL IPTEKKOM : Jurnal Ilmu Pengetahuan $\begin{array}{llll}\text { \& Teknologi Informasi, } & 17(1),\end{array}$ https://doi.org/10.33164/iptekkom.17.1.2015.31-38

Handayani, F. S., \& Adelin, A. (2019). Interpretasi Pengujian Usabilitas Wibatara Menggunakan System Usability Scale. Techno.Com, 18(4), 340-347. https://doi.org/10.33633/tc.v18i4.2882

Marcus, A. (2002). Return on investment for usable user-interface design: Examples and statistics. Aaron Marcus and Associates. Inc. Whitepaper.

Muqoddas, A., Yogananti, A. F., \& Bastian, H. (2020). Usability User Interface Desain pada Aplikasi Ecommerce (Studi Komparasi Terhadap Pengalaman Pengguna Shopee, Lazada, dan Tokopedia). ANDHARUPA: Jurnal Desain Komunikasi Visual \& Multimedia, 6(1), 73-82. https://doi.org/10.33633/andharupa.v6i1.3194 
Nugroho, K. T., Julianto, B., Intyanto, G. W., Munir, M. S., \& Nur M.S., D. F. (2020). Analisa Usability Website Akademi Komunitas Negeri Pacitan Menggunakan Metode Heuristic Evaluation. JISKA (Jurnal Informatika Sunan Kalijaga), 5(3), 185. https://doi.org/10.14421/jiska.2020.53-06

Prabowo, M., \& Suprapto, A. (2021). Usability Testing pada Sistem Informasi Akademik IAIN Salatiga Mengunakan Metode System Usability Scale. JISKA (Jurnal Informatika Sunan Kalijaga), 6(1), 38. https://doi.org/10.14421/jiska.2021.61-05

Pradini, R. S., Kriswibowo, R., \& Ramdani, F. (2019). Usability Evaluation on the SIPR Website Uses the System Usability Scale and Net Promoter Score. Proceedings of 2019 4th International Conference on Sustainable Information Engineering and Technology, SIET 2019, 280-284. https://doi.org/10.1109/SIET48054.2019.8986098

Salamah, I. (2019). Evaluasi Usability Website POLSRI Menggunakan System Usability Scale. JANAPATI, 8(3), 176-183.

Sauro, J. (2011). Measuring Usability with the System Usability Scale (SUS). MeasuringU. https://measuringu.com/sus/

Standard, I. (1998). Iso 9241-11. 1998.

Stone, D., Jarrett, C., Woodroffe, M., \& Minocha, S. (2005). User interface design and evaluation. Elsevier.

Sugiyono. (2014). Penelitian, Metode Pendekatan Kuantitatif, Kualitatif, Dan R\&D. Alfabeta.

Sujarweni, V. W. (2015). Statistik Untuk Bisnis Dan Ekonomi. Yogyakarta. Pustaka Baru Press.

Suryabrata, S. (1998). Metodelogi penelitian. Jakarta: Raja Grafindo Persada.

Suyanto, S., \& Ependi, U. (2019). Pengujian Usability dengan Teknik System Usability Scale pada Test Engine Try Out Sertifikasi. MATRIK: Jurnal Manajemen, Teknik Informatika Dan Rekayasa Komputer, 19(1), 62-69. https://doi.org/10.30812/matrik.v19i1.503

W Wahiddin, A R Syulistyo*, and M. N. S. (2021). Usability measurement for Sistem Proyek Akhir Manajemen Rekayasa Konstruksi ( SIPROK-MRK) measured with the system usability scale Usability measurement for Sistem Proyek Akhir Manajemen Rekayasa Konstruksi ( SIPROK-MRK) measured with the system usabili. IOP Conf. Series: Materials Science and Engineering. https://doi.org/10.1088/1757899X/1073/1/012015 